\title{
The Uncertain Structure of Process Review in the EU: Beyond the Debate on the CJEU's Weiss Ruling and the German Federal Constitutional Court's PSPP Ruling
}

\section{Oliver Gerstenberg ${ }^{1}[$}

Accepted: 17 November 2021 / Published online: 29 November 2021

(c) The Author(s) 2021

\begin{abstract}
The obligation to provide reasons (e.g. in Art. 296 TFEU) may appear rather a simple and straightforward, but in actual practice-as the mutually antagonistic Weiss rulings of the CJEU and the German Bundesverfassungsgericht ("BVG") amply demonstrate-is fraught with constitutional complication. On the one side, there lies the concern with a deeply intrusive form of judicial review which substitutes judicially determined "good" reasons for those of the reviewee decisionmakerlegislatures, administrative agencies, or, as in Weiss, the European Central Bank (ECB). On the other side lies the concern with judicial abdication in the face of technical expertise, uncertainty and complexity, turning the reason-giving requirement into a mere façade thereby placing democratic accountability in the modern administrative state beyond law's remit. Either way, normatively and conceptually, we seem left with a half-way house only. Drawing on the recent US administrative law discourse - the neo-Fullerian concept of an "internal morality of law" (Sunstein / Vermeule) and democratic experimentalism (Sabel / Kessler) - this paper explores the concept of process review as tertium datur. Process review responds to concerns over the rule of law and administrative discretion through indirect, procedural safeguards, by imposing requirements of reasoned justification, rather than through wholesale invalidation or aggressive substantive review.
\end{abstract}

Keywords Administrative law · Judicial review · European Central Bank · Court of Justice of the EU · Reason-giving · Legitimacy

Oliver Gerstenberg

o.gerstenberg@ucl.ac.uk

1 Faculty of Laws, UCL, Bentham House, 4-8 Endsleigh Gardens, London WC1H 0EG, UK 


\section{Locating the Paper: the European Central Bank on the Loose?}

“... it should be recalled that, in situations ... in which an EU institution enjoys broad discretion, a review of compliance with certain procedural safeguards including the obligation for the ESCB to examine carefully and impartially all the relevant elements of the situation in question and to give an adequate statement of the reasons for its decisions - is of fundamental importance." (CJEU, Weiss and Others, Case C-493/17, ECLI:EU:C:2018:1000, at 30).

An obligation to provide a reasoned justification for your actions and decisions may appear rather a simple and straightforward requirement on paper, but in actual practice-as the mutually antagonistic Weiss rulings of the CJEU ${ }^{1}$ and the German Bundesverfassungsgericht ("BVG") ${ }^{2}$ amply demonstrate-this obligation is fraught with constitutional complications. On the one side, there lies the concern with a deeply intrusive form of judicial review which substitutes judicially determined "good" reasons for those of the reviewee decisionmaker-legislatures, administrative agencies, or, as in Weiss, the European Central Bank (ECB). On the other side lies the concern with judicial abdication in the face of technical expertise, uncertainty and complexity, turning the reason-giving requirement into a mere façade thereby placing democratic accountability in the modern administrative state beyond law's remit. Either way, normatively and conceptually, we seem left with a half-way house only. This article-somewhat speculatively-explores the uncertain structure of process-review against the backdrop of both these rulings by asking whether a more dialogic and "experimentalist" mode of process review offers a tertium datur that can help resolving the existing impasse.

I emphasize "speculatively," because neither of the two rulings, given the degree of mutual acrimony involved, even remotely appears capable of lending talk about "dialogue" much empirical credence, let alone, of indicating a constructive way forward. No court wants to hear from another court that its ruling is simply "not comprehensible and must be regarded as arbitrary." 3 The CJEU's ruling-on this point, as I will argue, the BVG indeed is correct-leaves us with the dead end of excessive deference toward the ECB, given the latter's own accountability deficit. But if the CJEU falls victim to a fiction about accountability, the BVG's ruling, as I will argue, in contrast, engages in a fiction of its own about the legislative supremacy and sovereignty of the German Bundestag as a remedy and thus fails to resolve the accountability problem it identifies. Moreover, not only does the BVG's ruling leave us with a dead end as well for its inability to solve the problem of democratic accountability, but the ruling also, by declaring that the CJEU in Weiss acted ultra vires, amounts to "an attack on the European Union as a legally constituted community of European democracies," 4 as

\footnotetext{
1 CJEU, Weiss and Others, Case C-493/17, ECLI:EU:C:2018:1000.

2 BVG, Judgment of 5 May 2020, 2 BvR 859/15-PSPP.

3 BVG, PSPP, at headnote 2. And "simply not comprehensible" (116, 118) and "objectively arbitrary (118).

4 Meier-Beck 2020.
} 
another senior judge (of the German Federal Court of Justice) has described its likely effects, and, indeed, on democracy itself. ${ }^{5}$

Recall: Under the ECB's Public Sector Asset Purchase Programme (PSPP) the Eurosystem central banks purchased debt securities issued by the central governments of Eurozone Member States and other recognised agencies. ${ }^{6}$ In its Weiss ruling, on a reference from the BVG, the CJEU held that Decision 2015/7746 by which the ECB introduced the programme was not ultra vires and did not therefore violate the EU Treaties which only permit the ECB to pursue monetary but not economic policy. ${ }^{7}$ The principal criterion for determining whether action falls within the sphere of economic or monetary policy are the publicly declared objectives of the measure. The objectives of Decision 2015/774-a return of inflation rates to levels below, but close to, $2 \%$ over the medium term-squarely fell within the objective of price stability, and this finding was not vitiated by the fact that this objective could also, alternatively, be sought through economic policy measures. Hence, as the CJEU found, applying a light-touch manifest-error-of-assessment standard, Decision 2015/774 was indeed supported by a sufficient "specific statement of reasons"; the PSPP programme fell within the sphere of monetary and not economic policy and therefore within the scope of ECB competences; the programme was suitable and necessary to achieve its objectives, thus meeting the test of proportionality, and it also did not violate Article 123(1) TEFU which prohibits the monetary financing of the budget.

By contrast, the upshot of the BVG's ruling was that, in the BVG's view, the PSPP programme had to be considered an ultra vires act by the ECB "given the ECB's failure to substantiate that the programme is proportionate" (232). Accordingly, it was incumbent upon the German Bundestag to ensure that the ECB does conduct a hard-look proportionality assessment in relation to the ECB. In order to be "comprehensible," this hard-look review had to consider a wide array of interests-which are affected by what the BVG dubs the PSPP's "economic and fiscal policy effects" (a term not used by the CJEU) $)^{8}$ on "virtually all citizens".

This article proceeds as follows. In a first step (II.), it revisits the differences of outlook in the two rulings of the CJEU and the BVG. In a second step (III.), drawing on recent conceptions of a neo-Fullerian "internal morality" of administrative law (Sunstein / Vermeule) and democratic experimentalism (Sabel / Kessler), it explores

\footnotetext{
${ }^{5}$ As Weiler and Sarmiento 2020 have argued, the profound damage to the integrity of the EU's legal order and its rule of law cannot be overstated. If every constitutional or high court of each of our Member States were to emulate the German example, it would really spell the end of the EU as an integrated legal space of justice and the rule of law and fatally damage the single market.

${ }^{6}$ Decision (EU) 2015/774 of the European Central Bank of 4 March 2015 on a secondary markets public sector asset purchase programme, ECB/2015/10, 2015 O.J. (L 121) 20. Four decisions have subsequently amended Decision (EU) 2015/774: Decision (EU) 2015/2101, 2015 O.J. (L 303) 106; Decision (EU) 2015/2464, 2015 O.J. (L 344) 1; Decision (EU) 2016/702, 2016 O.J. (L 121) 24; and Decision (EU) 2017/100, 2017 O.J. (L 16) 51. Decision (EU) 2015/774 has been repealed by Decision (EU) 2020/188 of the European Central Bank of 3 February 2020 on a secondary markets public sector asset purchase programme (ECB/2020/9), 2020 O.J. (L 39) 12.

${ }^{7}$ See infra, at II. A.

${ }^{8}$ See infra, at II.A.
} 
the concept of process review and extends this concept to the present setting of the role of the CJEU in reviewing the ECB. In a third step (IV.), this paper addresses the conditions of process review by looking at its specific EU constitutional pluralist background: the relationship between the CJEU and the BVG. The paper concludes that the concept of process review_as envisaged by neo-Fullerian and democratic experimentalist approaches-may provide a shared common ground here, but also requires repair of the ethical commitments which the rule of law requires.

\section{The Clash over Proportionality: Differences Between the CJEU's Weiss Ruling and the BVG's PSPP Ruling}

A. The nexus of monetary and economic policy from the mutually antagonistic perspectives of the CJEU and the BVG

As regards the question of the ECB acting within the limits of the powers conferred upon it by primary law, the CJEU, drawing on the framework it has established in its 2015 Gauweiler ruling, ${ }^{9}$ in Weiss reiterates:

it is true that the ESCB must be allowed a broad discretion since, when it prepares and implements an open market operations programme, it is required to make choices of a technical nature and to undertake complex forecasts and assessments. The fact remains, however, that the Court is required to ascertain, in its review of the proportionality of the measures entailed by such a programme in relation to monetary policy objectives, whether the ESCB made a manifest error of assessment in that regard (rec. 24).

The CJEU, in this way, announces a policy of judicial deference toward the choices made by the ECB, on the basis of expertise, endorsing a manifest-error-ofassessment standard.

Article 3(1)(c) TFEU states that the Union is to have exclusive competence in the area of monetary policy for the Member States whose currency is the euro. In Weiss, the CJEU referred, to its previous rulings in Pringle and Gauweiler ${ }^{10}$ to the effect that, in order to determine whether a measure is part of monetary policy, the objectives of the measure must be taken into account (rec. 53). If it appears that an ECB programme falls within the area of monetary policy, then that programme may be validly adopted and implemented in so far as the measures that it entails are proportionate to the objectives of that policy.

The CJEU invoked two arguments to justify the objectives-based test. First, the textual argument that the TFEU does not make an absolute separation between economic and monetary policies, and second, factually, the inter-connectedness of monetary and economic policy. The CJEU insisted that a monetary policy measure

\footnotetext{
${ }^{9}$ CJEU, Gauweiler and Others,C-62/14, EU:C:2015:400, paragraph 41.

${ }^{10}$ CJEU, Pringle, C-370/12, EU:C:2012:756, paras 53 and 55, and Gauweiler and Others, C-62/14, EU:C:2015:400, para 46.
} 
cannot be equated with an economic policy measure merely because it may have indirect effects, which may also be sought in the context of economic policy.

As the CJEU explained, the primary objective of the EU's monetary policy must be to maintain price stability (rec. 51). This was the case: The relevant ECB decision (in its fourth recital) stated that it was intended to contribute to inflation rates returning to a level below, but close to $2 \%$ in the medium term (rec. 56). This objective, as the CJEU stated in more detail, is not objectionable as a concretization of the objective of maintaining price stability as the primary objective of the Union's monetary policy. So, the specification of this objective was "not vitiated by a manifest error of assessment" and did not go beyond the framework established by the FTEU.

This conclusion was not called into question (58) by the fact, relied on by the referring BVG, that the PSPP has a significant impact on the balance sheets of commercial banks and on the financing conditions of the Member States of the euro zone. It was never disputed that the PSPP, according to its rationale and modalities, may have an impact, both on the balance sheets of commercial banks and on the financing of the Member States covered and that such effects may also be sought through economic policy measures. But, as the CJEU reiterated, a monetary policy measure cannot be treated as equivalent to an economic policy measure for the sole reason that it may have indirect effects that can also be sought in the context of economic policy. ${ }^{11}$ A monetary policy measure cannot be treated as equivalent to an economic policy measure for the sole reason that it may have indirect effects that can also be sought in the context of economic policy (rec. 61). Accordingly, the CJEU emphasized (rec. 62) that it was unable to concur with the referring BVG's view that any effects of an open market operations programme that were knowingly accepted and definitely foreseeable by the ESCB when the programme was set up should not be regarded as "indirect effects" of the programme. For if the ESCB were precluded altogether from adopting such measures when their effects are foreseeable and knowingly accepted, that would, in practice, prevent it from using the means made available to it by the Treaties for the purpose of achieving monetary policy objectives and might-in particular in the context of an economic crisis entailing a risk of deflation-represent an insurmountable obstacle to its accomplishing the task assigned to it by primary law (rec. 67).

Consequently, as the CJEU elaborated, in order to exert any influence on inflation rates, the ECB necessarily had to adopt measures that have certain effects on the real economy, which might also be sought - to different ends-in the context of economic policy. In short, the CJEU thus stated that monetary policy measures necessarily have macroeconomic effects and that it was irrelevant that these effects could also be the objective of economic policy measures. In particular, as the CJEU pointed out, when the maintenance of price stability requires the ECB to seek to raise inflation, the measures that it must adopt to ease monetary and financial conditions in the euro area for that purpose may entail an impact on the interest rates of government bonds because those interest rates play a decisive role in the setting of

\footnotetext{
11 The CJEU here referred to its judgments of 27 November 2012, Pringle,C-370/12, EU:C:2012:756, paragraph 56, and of 16 June 2015, Gauweiler and Others, C-62/14, EU:C:2015:400, paragraph 52.
} 
the interest rates applicable to the various economic actors (66). If the ECB were precluded altogether from adopting such measures when their effects are foreseeable and knowingly accepted, that would, in practice, prevent it from using the means made available to it by the Treaties for the purpose of achieving monetary policy objectives and might--in particular in the context of an economic crisis entailing a risk of deflation-represent an insurmountable obstacle to its accomplishing the task assigned to it by primary law (67). Within the institutional balance established by the provisions of the TFEU, which includes the independence of the ESCB guaranteed by Article 130 and Article 282(3) TFEU, the authors of the Treaties did not intend to make an absolute separation between economic and monetary policies (60). Nowhere in its ruling did the CJEU use the notion of "economic policy consequences".

Consider now the BVG's ruling. In PSPP, the BVG acknowledged that "certain tensions are [...] inherent in the design of the European Union; they must be resolved in a cooperative manner, in keeping with the spirit of European integration, and mitigated through mutual respect and understanding." ${ }^{2}$ However, according to the BVG, the CJEU's approach "manifestly fails to give consideration to the importance and scope of the principle of proportionality" (119) in Art. 5(1) second sentence and Art. 5(4) TEU. The BVG essentially raises two points.

First, according to the BVG, proportionality analysis also applies to the division of competences. The CJEU's ruling therefore "is no longer tenable from a methodological perspective given that the CJEU completely disregards the actual effects of the PSPP" in its proportionality test (119). Therefore, the judgment of the CJEU manifestly exceeded the CJEU's own competences, resulting in a structurally significant shift in the order of competences to the detriment of the Member States. The CJEU ruling itself accordingly constituted an ultra vires act and thus has no binding effect in Germany (119). In other words, proportionality-according to the BVG's underlying hypothesis-must always also be observed already in the very distribution and division of competences (Article 5(1), second sentence, and (4) TEU). The CJEU's ruling was no longer justifiable from a "methodological perspective", because the actual effects of the PSPP are excluded (para. 119).

According to the BVG, the approach of the CJEU "to disregard the actual effects of the PSPP" (123) in the context of the proportionality test and its failure to carry out an evaluative "overall assessment and appraisal" (123), failed to meet the requirements for a "comprehensible review" (123) of compliance with the monetary policy mandate of the ECB. Thus, according to the BVG, the principle of proportionality could no longer fulfil its "corrective function for the purpose of safeguarding the competences of the Member States" (123), as provided for in Article 5 (1), second sentence, and (4) TEU. The CJEU's approach "essentially renders meaningless" the principle of conferral under Article 5 (1), first sentence, and (2) TEU (para. 123). In particular, proportionality becomes meaningless for distinguishing, in relation to the PSPP, between monetary policy and economic policy (127).

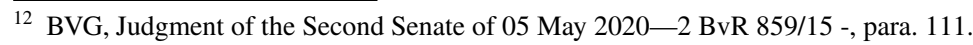


According to the proportionality test ("overall assessment and appraisal") which the BVG thought was missing from the CJEU's reasoning and which, according to the BVG, however, was necessary for the demarcation of competences between monetary policy and economic policy, the "monetary policy objective" is to be weighed against the "economic policy consequences" or the "economic and fiscal policy effects" (see, for example, paras 133 f., 138, 146, 163, 165, 167 f., 173, 176). The latter are extremely wide-ranging. They include "the effects of the PSPP on the banking sector" and the "the balance sheets of the Eurosystem (172); they furthermore include "the risk of creating real estate and stock market bubbles as well as the economic and social impact on virtually all citizens, who are at least indirectly affected inter alia as shareholders, tenants, real estate owners, savers or insurance policy holders", which "must not be completely ignored" (173). To serve the demarcation of competences between monetary policy and economic policy, it would have been incumbent upon the ECB "to weigh these effects and balance them, based on proportionality considerations, against the expected positive contributions to achieving the monetary policy objective the ECB itself has set. It is not ascertainable that any such balancing was conducted ... Neither the ECB's press releases nor other public statements by ECB officials hint at any such balancing having taken place" [176]. In other words, under the BVG's test, the ECB must balance effects on house prices, unemployment etc. against the negative effects of inflation: the decisive test is whether the monetary policy effects are disproportionately small to the economic policy effects, in which case the measure could not be qualified as a monetary policy measure according to the BVG.

Second, the BVG accused the CJEU of a fateful inconsistency in its proportionality analysis by departing from its own prior standards for the application of the principle of proportionality. In other contexts, the CJEU itself has held that the review of compliance with legal criteria would be deprived of effect if, in the event of doubt as to that compliance, the review would be left to the organisation intending to carry out the contested measure (145). The BVG here referred to the CJEU's fundamental rights jurisprudence, in particular, to the CJEU's ruling in Egenberger, ${ }^{13}$ arguing that it "is not ascertainable why a different standard should apply in relation to EU institutions such as the ECB, especially given that the CJEU has repeatedly emphasised the legitimising function of judicial review." Recall, in Egenberger, the CJEU explicitly rejected the jurisprudence of the BVG according to which the undisputed difference of treatment of a job applicant, by the Evangelisches Werk, was justified by the churches' right to self-determination under the German constitution, thereby extending the requirement proportionality analysis into the non-state sector of autonomy afforded to faith-based organisations.

\section{B. Responses to the BVG in the academic literature}

As regards the first argument: in particular, Meier-Beck has pointed out that the whole premise or underlying hypothesis of the BVG's argument-that the ECB's

$\overline{13}$ CJEU, C-414/16, EU:C:2018:257. 
competence in monetary policy must be distinguished from the economic policy competences of the Member States by means of a proportionality test (see explicitly para. 127) — "is not substantiated by a single sentence."14 The validity of this premise, however, is anything but evident; the CJEU obviously did not share it. The BVG's underlying hypothesis is anything but evident, because under Article 5(1) TEU, the principle of conferral of powers on the Union applies to the delimitation of competences. By contrast, the principles of subsidiarity and proportionality govern the use of EU competences.

As Meier-Beck explains, the proportionality test even in the narrower (i.e. the CJEU's) sense, i.e. the examination of whether the use of appropriate and necessary means to achieve the objective has consequences or secondary consequences, which are disproportionate to the intended effect, almost always requires a difficult weighing of numerous points of view. The uncertain and to a degree necessarily subjective result of such balancing is inappropriate to limit the responsibility or competence for the measure as such. But the BVG's proportionality test-which weighs monetary policy objective versus "'economic policy consequences" - is not a weighing of consequences of the kind familiar to lawyers and that courts can do, and it is not easy to understand what is actually meant by it. In a similar vein, Tridimas, in his comment on the rulings, has pointed out that the BVG's test would inevitably "turn proportionality in a wide-ranging inquiry on the likely macro-economic redistributive effects of ECB intervention which would be impossible to carry out."15

In other words, the BVG declared more or less all the economic effects of the PSPP to be economic policy effects, with the exception of the influence on the inflation rate itself. The monetary policy measure is - in terms of competences-all the more disproportionate and thus an ultra vires act, the stronger its macroeconomic effects and their consequences for public debt, bank capitalization, property values and much more besides will be, because they can only be forecast if the measure is adopted. As Meier-Beck wryly notes, "the only thing that is on the safe side of undoubted competence of the ECB is a probably ineffective monetary policy measure." In a similar vein, Tridimas has observed: the BVG's test "would ... turn proportionality in a wide-ranging inquiry on the likely macro-economic redistributive effects of ECB intervention which would be impossible to carry out [and] risks sacrificing the effective exercise of monetary policy in the altar of constitutional orthodoxy of a single Member State."16

As regards the second argument: Proportionality, as Tridimas has commented, is a standard not a hard and fast rule to be applied mechanically. Its contextualisation depends on a wide array of factors, including the right or interest affected, the degree of interference with that right, the status of the author of the measure, the aim pursued, and the context and the circumstances of the case. The case law of the CJEU routinely acknowledges that, in various sundry policy areas, the applicable standard is one of manifest error.

\footnotetext{
14 Meier-Beck 2020.

15 Tridimas 2020, p. 5 .

16 Ibid.
} 
As Meyer-Beck concludes, concerns regarding the PSPP and its proportionality "may be heard by all and may be serious or even resounding," and are shared by many observers. But they are to be examined by the CJEU. The BVG's underlying hypothesis of the ECB's exclusive competence only to pursue a "proportionate" monetary policy is a proposition about the content of Union law on which there is no consensus at present and which, accordingly, would should have been submitted by the BVG for a preliminary ruling from the CJEU.

As also Eleftheriadis has argued, the BVG's hypothesis that it is for the BVG to look at the proportionality of an EU legal measure at all (from an EU legal perspective) is neither explained nor substantiated. However, in claiming for itself this role, the BVG, alarmingly, also challenges the concept of supremacy ${ }^{17}$-a point to which I will return. ${ }^{18}$

\section{Two dead ends}

The non-dialogue between the BVG and the CJEU leaves us with two dead ends. The first dead end is one of the CJEU's making: the CJEU's manifest-errorof-assessment approach which focuses merely on declared "objectives" appears as excessively deferential vis-à-vis the ECB by nodding-through as an adequate "statement of reasons" just anything that the ECB publishes. The BVG's judgment correctly illustrates that the substantive problem of how to reconcile the independence of the $\mathrm{ECB}^{19}$ with accountability essentially remains unresolved in the CJEU's approach.

Thus, in his defense of the BVG's ruling, Dieter Grimm has argued that the BVG was justified in concluding that the CJEU had refrained from conducting any effective oversight of the ECB, thus giving the ECB carte blanche to freely determine the extent and scope of its mandate. ${ }^{20}$ The CJEU's response was insufficient to dispel the BVG's legitimate concerns about the ECB's accountability deficit. The CJEU itself had shown no real willingness to engage in judicial dialogue. Indeed, Grimm argues that the CJEU had it coming for a long time. According to Grimm, the CJEU has over time constantly been eroding the principle of conferral-the basis of the entire European order-causing deep rifts in the legal order of the Member States, for the most part in the interest of the four fundamental freedoms of the EU single market, and thus with a market-liberalising tendency. Whereas the CJEU insists that it is the only court with jurisdiction to assess whether a certain competence belongs to the EU and whether a legal act of the EU is covered by the competence in question, the BVG in contrast assumes that the power of review must be shared. Under the BVG's assumption, the CJEU reviews whether legal acts of the EU are compatible with the Treaties and such decisions are binding on the entire EU; by contrast,

\footnotetext{
17 Eleftheriadis 2020a, b.

18 Infra, section C.

19 Cf. Protocol (no. 4) on the Statute on the European System of Central Banks and the European Central Bank, Art. 7, at EUR-Lex-12016E/PRO/04-EN-EUR-Lex (europa.eu).

${ }^{20}$ Grimm 2020, p. 948.
} 
the BVG-like many other national constitutional courts-reviews whether there has been a permissible conferral of competences on the EU in relation to Germany.

In a similar vein, Takis Tridimas-while sharply critical of the BVG's ruling (cf. above)— too, accepts that the BVG in PSPP was "poignantly correct in identifying an accountability gap in the EMU structure" and exposing the design model of the EMU, where accountability mechanisms are few and fall short of democratic legitimization. The CJEU's strategy of judicial deference-its focus on the objectives of a measure as the determining criterion- "gives enormous discretion to its author to determine whether it is a measure of monetary or economic policy," leaving the decision-maker firmly in control. ${ }^{21}$

The second dead end is of the BVG's making. Consider two aspects. First, the BVG's proposed response to the accountability problem appears inadequate to resolve it. The BVG tries to resolve the accountability deficit of the ECB by trying to reinforce the legislative supremacy of the German Bundestag. While the BVG refers to "the spirit of European integration" (111) and the Basic Law's "openness to European integration" (112), it insists that what is it stake here are Germany's national "constitutional identity" and the "principle of democracy". In its ruling, the BVG claims for itself a democracy-reinforcing role: "When sovereign powers are transferred to the European Union, ... it must be ensured that the German Bundestag retain for itself functions and powers of substantial political significance" (113, 115). The BVG accordingly required the Federal Government and the Bundestag to take active steps seeking to ensure that the ECB conducts a proportionality assessment in relation to the PSPP. The Bundestag "must clearly communicate their legal view to the ECB or take other steps to ensure that conformity with the Treaties is restored" (232). But, citing its independence, the ECB-which, of course, is exclusively subject to the jurisdiction of the CJEU and accountable to the European Parliament-might just not bow to pressure at all or, rather, might reiterate that proportionality has duly been considered all along. ${ }^{22}$ The ECB might respond by attaching a more detailed proportionality analysis to its policy announcements. The ECB may simply show "linguistic sensitivity" 23 to German demands on proportionality. In the end, as regards the ECB's very real accountability deficit, not much will have changed. In other words, the BVG appears to engage in a fiction about Bundestag sovereignty in ways that fail to get at the core of the ECB's accountability problem.

The BVG reinforces its very own democratic deficit when it comes to competences. While the BVG accuses the CJEU of "crossing the limit" (113-15) and exceeding its competences-just as any other of the EU's multiple "institutions, bodies, offices and agencies" (111) might—it itself constantly pushes the envelope through its judicial activism by creating a pathway for litigants to initiate these legal actions in the first place. Under the German Basic Law, only individuals whose

\footnotetext{
21 Tridimas, op. cit.

22 See Mersch (2020): "The ECB's Governing Council constantly evaluates the potential side effects of its monetary policy measures - including the PSPP. This evaluation is part of the proportionality assessment underpinning the ECB's policy choices and is publicly available.".

23 Cf. Marsh 2020.
} 
constitutional rights are at stake have standing to bring a constitutional complaint before the BVG. Such a violation of an individual fundamental right, however, appears hardly self-evident when it comes to central-bank policies or the German government's response to them. On the politically and economically salient issue of the PSPP, no Member State or other institution of the EU had ever asked the CJEU to examine whether the ECB has exceeded its mandate. Yet, through a doctrinal-legal construction focused on the individual fundamental right to vote and the Bundestag's budgetary autonomy, the BVG has afforded itself the competence, in response to the constitutional complaint of even a single citizen (in PSPP, a group of around seventeen hundred German citizens), to put the ECB's monetary policy, and the reactions of German Parliament and Government to it, to the test of judicial scrutiny. ${ }^{24}$ Indeed, the BVG actively invites and even encourages litigants to initiate these legal actions on order to "protect the holders of the right to vote from a loss in substance of their sovereign power" (113). This suggests a turn by the BVG toward an "inward interpretation of its constitution," as Eleftheriadis has observed: a turn that entails a threat to the primacy of EU law. ${ }^{25}$ Contrary to Honeywell ${ }^{26}$ (where ultra vires review was limited to constitutional essentials), following Weiss, "even the smallest or a merely procedural failure of the CJEU to effectively monitor the EU's competences can be 'structurally significant' form a 'constitutional' point of view." 27 Just any transfer of rights to the EU that is not explicitly endorsed by the German Bundestag or that might affect its budgetary autonomy now becomes challengeable as a violation of the individual right to vote. ${ }^{28}$ Any decision by a national court with EU-wide implications and on which the future of the euro may depend appears particularly precarious in terms of democracy, ${ }^{29}$ especially now as the proportionality of the ECB's Pandemic Emergency Purchase Programme (PEPP) has been negotiated in proceedings before the BVG. ${ }^{30}$

The BVG judgment then leaves you with the following impasse. The BVG throws the ECB's accountability deficit into sharp relief, but fails to resolve the problem by relying on a fiction about extant political supremacy of the Bundestag. Moreover, the BVG judgment involves a heavy cost: an attack on the EU as a legally constituted community that inflicts profound damage to the integrity of the EU's legal

\footnotetext{
${ }^{24}$ On this aspect, cf. Meier-Beck and also Pistor 2020, and Mayer 2020, pp. 733-69. Pistor and Mayer, though, seem to assume that strengthening oversight by the Bundestag is the way forward.

25 Cf. Eleftheriadis 2020a, b (criticising the "inwardness" of the German BVG).

26 BVG, Order of the Second Senate of 6 July 2010-2 BvR 2661/06.

27 Eleftheriadis, op. cit.

28 On the (non-) dialogue which has taken place between the CJEU and the German BVG for a long time, see more fully infra, at section IV.

29 This issue was already raised by the two dissenting judges in the BVG's Gauweiler ruling of 2014 (2 BVR 2728/13)_Lübbe-Wolff and Gerhardt. Cf. also Alter 2021 pp. 269-284 (arguing that judicial or individually triggered administrative review of central bank decisions or proportionality review does not contribute to improving central bank economic policymaking).

30 BVG, Eigenmittelbeschluss-Ratifizierungsgesetz-2 BvR 547/21 - of 16 March 2021. And the Order of 15 April 2021-2 BvR 547/21 - published on 21 March 2021 where the Second Senate of the Federal Constitutional Court rejected an application for preliminary injunction directed against the Act Ratifying the EU Own Resources Decision (Eigenmittelbeschluss-Ratifizierungsgesetz - ERatG).
} 
order and its rule of law. ${ }^{31}$ If every constitutional or high court of each of our Member States were to emulate the German example, it would really spell the end of the EU as an integrated legal space of justice and the rule of law and fatally damage the single market.

\section{Modalities of Judicial Review Under Conditions of Heightened Uncertainty}

\section{A. Rule of law and process review}

Given these dead ends, is there a meaningful way for the CJEU to review the reasoning of apolitical independent expert bodies such as the ECB? The ECB, as AG Jacobs back in 2002 observed, "is ... subject to the principle of the rule of law [which is enshrined in Art. 2 TEU] ... [and] to the jurisdiction of the European Court of Justice and bound by Community law." 32

According to the CJEU's settled case law, reiterated in Weiss, "the statement of reasons for an EU measure, which is required by the second paragraph of Article 296 TFEU, must show clearly and unequivocally the reasoning of the author of the measure in question, so as to enable the persons concerned to ascertain the reasons for the measure and to enable the Court to exercise its power of review." The statement of reasons "is not required to go into every relevant point of fact and law" (rec. 31). Since "questions of monetary policy are usually of a controversial nature and in view of the ESCB's broad discretion," according to the CJEU, "nothing more can be required of the ESCB apart from that it use its economic expertise and the necessary technical means at its disposal to carry out [a reasoned analysis] with all care and accuracy." ${ }^{33}$ Judicial review is light-touch only: the applicable standard is one of "manifest error of assessment."

In contrast with the CJEU's manifest-error standard, the BVG claims that proportionality must also play a decisive role in demarcating the competences of the EU vis-à-vis its Member States, not only in merely assessing whether the exercise of an existing competence under Art. 5 (1) TEU is lawful. The BVG's preferred alternative approach is to institute, in this way, substantive constitutional limitations on ECB authority that would fundamentally restrict what the ECB may do. The familiar twofold rule-of-law based standard concern about "standardless" delegations, which

\footnotetext{
31 Sarmiento and Weiler 2020.

32 CJEU, Case C-11/00, Commission v ECB, EU:C:2003:395 - “OLAF”, at 158. Art. 263 TFEU, by explicitly also mentioning the ECB, clarifies that the ECB's independence does not shield its acts from judicial review by the CJEU. In addition, Article 35 of theStatute of the ECB also clarifies that the "acts and omissions of the ECB" to review or interpretation by the CJEU "in the cases and under the conditions" laid down in the TFEU. Cf. Protocol No. 4 on the Statute of the European System of Central Banks and of the European Central. Bank, 2016 O.J. (C 202), 230, 245.

33 CJEU, Case C-493/17, Weiss, ECLI:EU:C:2018:1000, par. 91 (Dec. 11, 2018) citing Case C-62/14, Gauweiler,
}

ECLI:EU:C:2015:400,par 75 (June 16, 2015). 
the BVG in its response to Weiss articulates, is this: (i) Judicial deference to the ECB on questions of law is an encroachment on the judicial power-an abdication of the CJEU's obligation to say what the law is. (ii) Judicial deference further weakens the already weak chain of accountability from the German people to the ECB wielding excessive discretion.

Is a tertium datur possible? The requirement of reasoned justification is, of course, one of the mildest forms of judicial monitoring of - and one of the mildest constraints on-administrative discretion. ${ }^{34}$ Reason giving deeply resonates with contemporary liberal political thought. As John Rawls wrote, "the idea of political legitimacy" is that "our exercise of political power proper only when we sincerely believe that the reasons we offer for our political actions-were we to state them as government officials - are sufficient, and we also reasonably think that other citizens might also accept those reasons." 35 Contemporary administrative law discourse, especially in the US context, has accordingly begun to explore a constructive proceduralist escape from the present predicament (exemplified by the two rulings).

In their jointly authored defense of the modern administrative state, Sunstein and Vermeule take concerns about violations of the rule of law, excessive administrative discretion, arbitrariness, and the erosion of judicial power seriously. ${ }^{36}$ These concerns, as they show, feed into persistent objections to the modern administrative state as simply unconstitutional when measured against a default common-law baseline, supposedly justified on either libertarian or originalist grounds. Noting that current administrative law is riven by severe conflict between critics of administrative discretion, on the one hand, and those who, by contrast, insist that the administrative state in itself is indeed "a clear reflection of democratic will [and] entirely legitimate on constitutional grounds", ${ }^{37}$ on the other, Sunstein and Vermeule suggest that administrative law needs to establish "a common framework" to regulate and civilize, without eliminating, those ongoing disagreements about the scope, aims, and powers of the administrative state, and to ensure they "can occur in a productive, structured way." 38 To that end, Sunstein and Vermeule draw on Fuller's concept of an "internal morality" of (administrative) law. Rule of law-based concerns can accordingly be countered, Sunstein and Vermeule argue, rather than through wholesale invalidation or aggressive substantive review, by a set of judicially legible "surrogate procedural principles." 39 The role of these indirect surrogate or essential safeguards is to "channel agency discretion" and to ensure that "agencies' official declarations are congruent with their actual motivations and behaviour". These surrogate safeguards are elaborations of "administrative law's implicit procedural

\footnotetext{
34 See already Shapiro, 1992, p. 181.

35 Rawls, 1999, p. 578.

36 Sunstein and Vermeule 2020.

37 Sunstein and Vermeule 2020, p. 3.

38 Sunstein and Vermeule 2020, p. 6.

39 Sunstein and Vermeule 2020, p. 12.
} 
logic." ${ }^{40}$ They do not "place rigid procedural limits on agencies", but merely require independent agencies "to provide a reasonable explanation of their procedural (and other) choices, connecting them to their underlying programmatic aims." While agencies must enjoy expansive authority, those reviewable safeguards ensure that agencies' official declarations are congruent with their actual motivations and behavior: "stated justifications must not be impossible to square with the actual behaviour of the officials who state them. ${ }^{41}$ Courts, according to this neo-Fullerian approach, "often do best by asking that agencies justify their choices, taking account of the uncertainty of the relevant policy environment." ${ }^{42}$ These safeguards amount to judicially-monitored "checks and limits that promote fidelity to law and that call for reasoned justifications." ${ }^{43}$ Indeed, Sunstein's and Vermeule's claim is that administrative law's compliance with Fullerian principles is "constitutive of legality" 44 and thus helps to legitimate the administrative state.

However, given the backdrop of deep and persistent disagreements about the modern administrative state and its legitimacy, which Sunstein and Vermeule take as their starting point, this latter claim raises the question why the morality of administrative law is different from constitutional law. ${ }^{45}$ Disagreements about the administrative state will, of course, translate into contextual disagreements about the endlessly contested applied meaning of the term "surrogate safeguards" as part of the internal morality of (administrative) law. The neo-Fullerian account invites the question whether recourse to a concept of an internal morality of law is necessary at all in an approach that is focused on reasoned justification. A democracy-minded critique insists that the applied meaning of the internal morality of administrative law cannot remain external to the process of reasoned justification itself. ${ }^{46}$ I will return to this point below (section IV.).

Despite important differences of theoretical approach, in a similar way, yet without reference to an inner morality of law, also Sabel and Kessler, from the vantage point of democratic experimentalism, insist that, properly understood, "[b]oth process review and internal administrative law ... can improve the incentives for sound reason-giving." ${ }^{47}$ Process review, as both authors argue, "encourages agencies to acknowledge uncertainty and manage it in a reasonable manner" ${ }^{48}$ in an interregnum where principal-agent relationships and hierarchically ordered authorities can no longer be relied upon to legitimate administrative action. The reviewing court

\footnotetext{
${ }_{40}$ Sunstein and Vermeule 2020, p. 18.

41 Sunstein and Vermeule 2020, p. 140.

42 Sunstein and Vermeule 2020, pp. 3, $17 \mathrm{ff}$.

43 Sunstein and Vermeule 2020, p. 144.

44 Sunstein and Vermeule 2020.

45 I am grateful to both Chuck Sabel and an anonymous peer-reviewer for raising this question.

46 Recall the famous critique by J. Shklar 1964/1986, p. xii, of Fuller's vision of an inner morality of law, even when broadened to include meeting the expectations of the citizenry at large: "Its standards could be met by any rigid bureaucratic regime as long as its repr4ssions were not random and the expectations of its unfortunate citizens were small.".

47 Sabel and Kessler 2021, p. 202.

48 Sabel and Kessler 2021, p. 200.
} 
must monitor whether "the agency's decisions in the form of guidance are well-considered, responsive to objections, and consistent with prior explanations of agency behavior and previously established regulatory presumptions" 49 and whether "the agency has acknowledged its departures (or refusals to change course), and whether it has given plausible reasons for its choices." 50 In the course of process review, as agencies engage in a justificational process, the reviewing court will gradually develop strategies of deference toward the "persuasive quality of agency decisionmaking ..." T1 To summarize, process review, in both the neo-Fullerian and the democratic experimentalist variant, moves beyond judicially-quietist deference by courts to apolitical expert bodies, and can be characterised as justification-enhancing, where the meaning of good reasons is never given ex ante but can only be established piecemeal in the very process of reason-giving itself.

\section{B. The ECB: proportionality outside the courts}

The idea of process review-as envisaged both by Sunstein and Vermeule and by Sabel and Kessler-can add flesh to the bare bones of the CJEU's "manifest error of assessment" standard in ways that point beyond mere judicial deference and quietism. The relevant reviewable process here is the ECB's contextual process of "reasoned analysis."

Recall that according to the framework provided by Art. 127 (1) TFEU, the ESCB.

[w]ithout prejudice to the objective of price stability, ... shall support the general economic policies in the Union with a view to contributing to the achievement of the objectives of the Union as laid down in Article 3 of the Treaty on European Union.

Art. 3 TEU, referred to in Art. 127 (1) TFEU, in turn, provides that the EU "shall work for the sustainable development of Europe based on balanced economic growth and price stability, a highly competitive social market economy, aiming at full employment and social progress, and a high level of protection and improvement of the quality of the environment." The EU "shall combat social exclusion and discrimination," and shall promote "solidarity between generations" and "economic, social and territorial cohesion," as well as "solidarity among Member States."

Next, notice that, in its various official declarations, the ECB expresses a succinct awareness of its own accountability (or "democratic legitimacy") deficit. Independence was, of course, granted to central banks in order to shield them from short-term political influence when fulfilling their narrow mandate of ensuring price stability. However, the ECB's specific accountability deficit results from-and is exacerbated by - two combined aspects. First, as Yves Mersch, a Member of the Board of Governors of the ECB, has pointed out, by the fact that the euro area is not a nation

\footnotetext{
49 Sabel and Kessler 2021, p. 199 f.

50 Sabel and Kessler 2021, p. 200.

51 Sabel and Kessler 2021, p. 201.
} 
state. In the euro zone a single European monetary policy co-exists with national or shared sovereignty in various policy domains, such as fiscal and labour market policies. $^{52}$ The interests of supranational policies must accordingly be aligned with nonharmonised national policies and their requirements. Second, the ECB's increased adoption of so-called unconventional monetary policy measures-such as the PSPP - has the problematic effect, from the standpoint of democratic legitimacy, of central banks ever more extensively influencing the distribution of income and wealth and subsidising the financial sector at the expense of society as a wholepolicy areas which uncontroversially require a high degree of democratic legitimacy and control. ${ }^{53}$

In response to its accountability deficit, the ECB has begun to engage in a practice of proportionality analysis. As Mersch explains, the ECB's proportionality analysis is structured by three steps: "the ECB's actions must be suitable to address the identified risks to price stability." 54 Second, the ECB's measures must be necessary to achieve their intended objective. In other words, "alternative monetary policy measures that entail more limited action would not enable the objective to be achieved as effectively and rapidly." Third, proportionality stricto sensu implies that "the expected benefits of the ECB's actions must outweigh their costs." In other words, the ECB as a policymaker must take into account not only the primary impact its tools have for their primary purpose, but "also any potential side-effects." ${ }^{25}$ These are wide-ranging, open-ended and can only be established on a rolling basis. Indeed, a useful illustration of this kind of non-judicial proportionality analysis can be found in the Governing Council of the ECB's Account of the monetary policy meeting of June 3-4, 2020, ${ }^{56}$ after the BVG's ruling. The document, at various instances, highlights the fact that the ECB's monetary policy baseline "was surrounded by an exceptional degree of uncertainty." Given heightened uncertainty, the "proportionality assessment of any monetary policy measure" required "judgement as to whether other policy measures were available that were as effective and efficient while offering a better balance between intended and unintended effects" and a further guiding consideration was whether "the additional monetary policy stimulus went hand in hand with the measures taken by euro area governments and European institutions to ensure sufficient healthcare resources and to provide support to affected companies, workers and households." These considerations resonate with Art. 3 TEU. The condition of uncertainty in this way shapes and re-shapes how proportionality as governance is to be understood and operationalized.

One may summarize as follows. Courts, under conditions of heightened uncertainty, cannot impose criteria of "reasoned analysis" in advance and from the outside through judicially-supremacist review. However, the CJEU can exert a more indirect

\footnotetext{
52 Mersch 2017.

53 Mersch 2017. Cf. also the analysis by Amtenbrink 2019a, b, p. 168. See also Amtenbrink 2019a, pp. $305 \mathrm{ff}$..

54 Mersch 2019.

55 Cf. Mersch 2019. See also Egidy 2012, p. 285-308.

56 Account of the monetary policy meeting of the ECB Governing Council, Frankfurt am Main, June 3-4, 2020, at https://www.ecb.europa.eu/press/accounts/2020/html/ecb.mg200625 fd97330d5f.en.html.
} 
role by regularizing and routinizing the ECB's process of contextual constant evaluation. Process review does not require the CJEU to substitute its own proportionality analysis for that of the ECB. Yet, in exerting its more indirect monitoring role, the CJEU can scrutinize whether, in the ECB's decisionmaking, there is a track record of evidence of self-revision and learning and whether decisions are consistent with preliminary criteria of proportionality that have materialized in the ECB's very process of ongoing evaluation itself. The CJEU will draw attention to the abstractly stated substantive commitments in Art. 3 TEU (referred to in Art. 127 (1) TFEU) and instigate discussion around them-and on how best to contextualise them. In so doing, the CJEU will require the ECB to provide a reasonable explanation of their procedural (and other) choices, connecting them to their underlying programmatic aims of ensuring price stability. The CJEU-possibly in response to repeat preliminary references from national courts - can indicate where, in the process of proportionality analysis undertaken by the ECB, the burden of proof lies; how that burden can be met; and what the normative stakes are; eventually, the CJEU can ensure compliance with an emergent best practice consensus on what can count as meeting the requirement of "reasoned analysis". Process review is both procedural and substantive-but not merely deferential to the ECB's proportionality assessments. It introduces, if you will, an element of normative hybridity - a constant irritation of the ECB's internal proportionality assessments by constitutional-normative considerations flowing from the broad commitments enshrined in primary EU law. In this way, the CJEU can become a critical interface between the ECB and the wider European public. Further research would need to elucidate the role which "monetary dialogue" between the ECB and the European Parliament according to Art. 284 TFEU may play a role in this connection.

\section{How Is Process Review Possible? Constitutional Pluralism and the Interplay Between the CJEU and National Constitutional Courts}

Can process review provide a bridge between the mutually antagonistic outlooks of the CJEU and the BVG? The Weiss / PSPP episode offers a new reminder of the unresolved problems of EU constitutional pluralism, which, in turn, can be seen as a local manifestation of the global problem of reasonable disagreement in constitutional law and interpretation more generally.

The problem of reasonable constitutional-interpretive disagreement is wellrehearsed in constitutional theory. ${ }^{57}$ A legitimacy-conferring constitution is supposed to serve as a justificational framework which reasonably disposed citizens can share, despite a virtual certainty that most of the citizens will regard some of the political or legal outcomes issuing from that framework as improvident or even seriously unjust and morally or ideologically repugnant. According to the

\footnotetext{
57 On the following, cf. Michelman 2019, pp. 59-75; and, with specific reference to the US context, Fallon 2018, p. $20 \mathrm{ff}$.
} 
proceduralizing logics of modern constitutionalism, as long as those outcomes can be thought to fall within the broad framework provided by a good-enough constitution, ongoing mutual collaboration between ideologically diverse citizens can be expected to remain morally warranted. However, in contemporary deeply divided societies the meaning of a good-enough constitution is itself open to deep, legitimacy-endangering moral dissensus in the context of particular controversies. Moral dissensus will extend to the constitutional framework itself_-in particular, where balancing is required and where "weight" must be assigned to conflicting considerations - and the constitution's proceduralizing logics may fail, and this criticism just as much extends to the concept of "surrogate safeguards" as part of an internal morality of administrative law. These problems are further exacerbated by constitutional pluralism in the EU, ${ }^{58}$ where the possibility of a shared framework is in doubt.

Discussions on the antagonistic consensus between the BVG and the CJEU and the limits of their respective prerogatives have been ongoing for decades. ${ }^{59}$ These discussions initially arose from the BVG's assertion that "as long as" there were no sufficient guarantees within the EU legal order of fundamental human rights, it would refuse to accept the primacy of EU law and revert to upholding the fundamental rights guaranteed by the German Constitution. ${ }^{60}$ In Internationale Handelsgesellschaft, ${ }^{61}$ the CJEU took to its logical extreme the principle of supremacy of EU law by reassuring national constitutional courts that a corpus of fundamental rights was written into EU law and formed "an integral part of the general principles of Community law" which the Court of Justice protected. The CJEU opened the road toward an expansion of fundamental rights by assuring Member States that national constitutions provide inspiration so as to achieve normative continuity and equivalence, but by simultaneously insisting that it was for the CJEU to do the fundamental-rights balancing. The CJEU in this way strengthened the rule of law element in the internal market; however, the incorporation of general principles into EU law unavoidably widened the scope for interpretive disagreement at the level of application. ${ }^{62}$

In its Maastricht and Lisbon judgments, the BVG extended its scope of review beyond fundamental rights to ultra vires (competence) review, including the

\footnotetext{
${ }^{58}$ For an illuminating recent of constitutional pluralism, see Flynn 2019, esp. ch. 1. See also Gerstenberg 2020, pp. 199-227.

${ }^{59}$ For a recent summary and discussion, cf. Basedow et al. 2021, pp. 188-207; Haltern 2021, pp. 208240.

${ }^{60}$ BVG, Wünsche Handelsgesellschaft [1987] 3 CMLRev. 225 (BverfG)—“Solange II" [BVerfGE 73, 339, 359-61 (1986)].

${ }^{61}$ CJEU, Case 11/70, Internationale Handelsgesellschaft mbH.

${ }^{62}$ Does, for example, the right to fair trial (Art. 47 CFREU) in the context of the European arrest warrant mean that a conviction in absentia is possible if sufficient safeguards for the accused were provided—or must the prohibition be absolute? Cf. CJEU, Melloni - CJEU (Grand Chamber) Case C-399/11 versus the Spanish Constitutional Court, Tribuna Constitucional, Pleno. Sentencia 26/2014, de 13 de febrero de 2014, and BVG, Order of the Second Senate, of 15 December 2015, 2 BvR 2735/14. Does clarification of the meaning of the term "genuine, legitimate and justified occupational requirement" in Article 4(2) of Directive 2000/78 involve proportionality analysis—or must the constitutionally protected prerogative of the church and faith-based organisations to decide whom to employ and under what conditions absolutely prevail? Cf. CJEU, C-414/16, EU:C:2018:257 (Egenberger) versus BVG, Order of the Second Senate of 22 October 2014-2 BvR 661/12.
} 
competence of the CJEU. In Lisbon, it established a "constitutional identity review" which covers core areas of German statehood, the control of which must remain at the national level, including among others the democracy principle, the rule of law, and human dignity. In Honeywell, ${ }^{63}$ the BVG emphasized that unavoidable tensions between the CJEU and the BVG were to be "harmonized cooperatively in accordance with the European integration idea and relaxed through mutual consideration" and in ways "open toward European law." The BVG declared that the CJEU was "not precluded from refining the law by means of methodically bound case-law," but that any "further development of the law" was "above all not permissible where case-law makes fundamental policy decisions over and above individual cases" and where further development of the law "causes structural shifts to occur in the system of the sharing of constitutional power and influence." The CJEU-according to the BVG-had "a right to tolerance of error." In so doing, the BVG, adopting a deeply ambivalent outlook, arguably assimilated the CJEU's jurisprudence, against the baseline of the German constitution, more to an exercise of administrative power by an agency than see it as judicial power proper.

Against this background, how is process review possible? Process review involves a retreat from judicial supremacy-but never to the point of permanent postponement of substantive resolution and of making judicial review redundant. ${ }^{64}$ Instead, the reviewing court can exert a meaningful role by instigating-and providing a recursive framework for-a justificational process through imposition of indirect procedural safeguards as suggested by neo-Fullerian and democratic-experimentalist accounts.

In the Weiss / PSPP episode, this justificational "game" involves three institutional players: the reviewing CJEU; the ECB engaging in rolling proportionality analysis; the national constitutional courts through repeat preliminary references. ${ }^{65}$ Under conditions of heightened uncertainty, there is no hierarchy: no player is in a privileged position of synoptic oversight. Moreover, there is not one single monolithic "democratic deficit" that hangs over the EU, but it has many sides ${ }^{66}$ : each of the three actors (CJEU, BVG, ECB) faces its own democratic deficit. To mitigate these multiple democracy deficits, the normative stakes and the meaning of procedural safeguards would accordingly have to be clarified through horizontal collaboration between the CJEU as a supranational court, the ECB as an expert body, and the national constitutional courts which can draw attention to urgent domestic concerns-ultimately subject to ongoing scrutiny by a vigilant democratic public. Indeed, as theories of democratic experimentalism have emphasized, the condition

\footnotetext{
63 BVG, Order of the Second Senate of 6 July 2010 - 2 BvR 2661/06.

64 For an argument in this direction, Gerstenberg 2018.

65 An example for the latter may be the Taricco adjudication: Corte cost., 10 aprile 2018, n. 115, ECLI:IT:COST:2018:115 [hereinafter Taricco] (It.); CJEU C-105/14, Taricco and others, ECLI:EU:C:2015:555 [hereinafter Taricco I]; Corte cost., 26 gennaio 2017, n. 24, Foro it. 2017, II, 394 (It.); Case C-42/17, M.A.S. and M.B., ECLI:EU:2017:936 [hereinafter Taricco II].

66 On this idea, Tucker 2018.
} 
of heightened uncertainty does not necessarily imply democratic degradation, but may actually favour the disposition to engage in collaborative-democratic-reason-giving all around-in a world where it becomes riskier and more costly to rely on familiar strategies and assumptions. In this collaborative process, "ideas of what is possible individually and jointly begin to change; changing ideas of possibilities prompt reconsideration of common interests and how to pursue them, and with whom." ${ }^{67}$ However, as Weiler has pointed out, the damage in the Weiss / PSPP scenario might have been even worse, if the BVG had indeed made a second reference and then rejected it. ${ }^{68}$

Given the precarious nature of horizontalized collaborative constitutionalism, the EU experience may therefore add the following to the debate on the neo-Fullerian "internal morality of law" and on democratic experimentalism. On the one hand, there is no apolitical administrative law, ${ }^{69}$ but the meaning of its procedural safeguards is constantly transformed in the justificational process these safeguards facilitate. Administrative law is never outside or beyond the constitution, but fully constitutionalized. However, on the other hand, the ongoing justificational process envisaged by deliberation-enhancing approaches depends on a repair of corresponding collaborative ethical commitments on which justificational ascent toward a shared normative framework, in turn, depends. Here is where empirical doubts lie and where my observations remain speculative. The German BVG might retreat from its quasi-originalist stance and inwardness ${ }^{70}$ and more strongly than before draw necessary consequences from the fact that Europe-friendliness forms part of Germany's constitutional identity as a conditio sine qua non. The CJEU, in turn, might retreat from its hands-off intergovernmentalist stance which also pervades its new case law on fundamental rights. ${ }^{71}$ Only then could both courts-in response to heightened uncertainty-begin to work toward a shared framework for ongoing negotiation extended through time in a context in which other institutional actorssuch as the ECB, engaging in proportionality analysis-and the wider EU public need to be brought on board if solutions are to endure.

\section{Conclusion}

The obligation "to state ... reasons" enshrined in Art. 296 TFEU (and also in Art. 41 (2) (c) CFREU) poses a familiar dilemma. On the one side, there is the persistent concern with democratically unaccountable "standardless" delegation of decisionmaking power to independent expert bodies. On the other side, there lies the concern with a deeply intrusive supremacist form of judicial review

\footnotetext{
${ }^{67}$ C.F. Sabel 2012. See also Sabel and Victor 2022.

68 Weiler, Why Weiss? 2021, p. 187.

${ }^{69}$ Cf. Otto Mayer's much-quoted famous dictum: "administrative law persists, constitutional law changes.” In Preface to: Mayer 1924.

70 For a critique of inwardness, see Eleftheriadis 2020a, b.

71 CF. CJEU, C-336/19 of 17. December 2020 - ritual slaughter; see also Joined Cases C-804/18 and C-341/19 of 15. July 2021—WABE and MH Müller Handel, on headscarves in private employment.
} 
which substitutes judicially determined "good" reasons for those of the reviewee decisionmaker. Drawing on the recent US administrative law discourse-the concept of an "internal morality of law" and democratic experimentalism-this article has explored the concept of process review as tertium datur. Process review has an uncertain structure. On the one hand, it involves a retreat from judicial supremacy, but does not collapse into mere acquiescence in response to heightened uncertainty and moral dissensus, on the other. Process review responds to concerns over the rule of law and administrative discretion through indirect, procedural safeguards, by imposing requirements of reasoned justification, rather than through wholesale invalidation or aggressive substantive review. Process review does not impose rigid procedural limits on the reviewee ECB, but requires reasonable explanations for the ECB's independent policy choices by asking whether the ECB's rolling proportionality analysis is responsive to objections and consistent with its publicly declared programmatic substantive commitments. The CJEU can routinize the ECB's process of proportionality analysis by monitoring whether there is a consistent track record of evidence of self-revision and by indicating where the burden of proof lies and in response to what concerns.

However, in the Weiss / PSPP episode, there were three institutional players in a relationship - the CJEU, the ECB, and the BVG, each of them haunted by their own "democratic deficit." What may count as a "reasonable" in terms of justification is also influenced by ongoing constitutional-pluralist negotiation between the CJEU and the BVG which connects the requirement of reasoned justification to the democratic concerns emerging from national constituencies. The framework of justification in this way extends through time across all the three actors-including the wider domestic and European public.

What the Weiss / PSPP episode brings out, is that the "internal morality of law" and democratic experimentalism depend on corresponding collaborative ethical commitments. The idea of a meaningful "we" may appear elusive and admittedly—as I warned you at the outset-speculative. Collaborative negotiation may go awry. But if we agree on anything, it should be that no institutional participant in the CJEU/ECB/ BVG trialogue can achieve anything without the help and collaboration of the others.

Acknowledgements For comments on this paper, I would like to thank Carsten Gerner-Beuerle, Cameron Hardie, Charles F. Sabel, Albert Weale and two anonymous peer reviewers.

\section{Declarations}

Conflict of Interest The author declares no competing interests.

Open Access This article is licensed under a Creative Commons Attribution 4.0 International License, which permits use, sharing, adaptation, distribution and reproduction in any medium or format, as long as you give appropriate credit to the original author(s) and the source, provide a link to the Creative Commons licence, and indicate if changes were made. The images or other third party material in this article are included in the article's Creative Commons licence, unless indicated otherwise in a credit line to the material. If material is not included in the article's Creative Commons licence and your intended use is not permitted by statutory regulation or exceeds the permitted use, you will need to obtain permission directly from the copyright holder. To view a copy of this licence, visit http://creativecommons.org/licen ses/by/4.0/. 


\section{References}

Alter KJ (2021) When and how to legally challenge economic globalization: a comment on the German Constitutional Court's false promise. I CON 19(1):269-284. https://doi.org/10.1093/icon/moab014

Amtenbrink, F (2019) The European Central Bank's intricate independence versus accountability conundrum in the post-crisis governance framework, in: Maastricht. Journal of European and Comparative Law 26(1) 165-179, at 168. https://doi.org/10.1177/1023263X18822789

Amtenbrink F (2019b) Independence and accountability in the New Age of European Central Banking: revisiting Gormley and De Haan's "“The democratic deficit of the European Central Bank." In: Internal T (ed) F Amtenbrink, G Davies, D Kochenov, and J Lindbloom. Cambridge University Press, Market and the Future of European Integration, pp 305-321

Basedow J et al (2020) (2021) European integration: Quo vadis? A critical commentary on the PSPP judgment of the German Federal Constitutional Court of May 5. I CON 19(1):188-207. https://doi. org/10.1093/icon/moab017

ECB Governing Council (2020) Account of the monetary policy meeting of the June 3-4, 2020, at https:// www.ecb.europa.eu/press/accounts/2020/html/ecb.mg200625 fd97330d5f.en.html

Egidy S (2021) Proportionality and procedure of monetary policy-making. I CON 19(1):285-308. https:// doi.org/10.1093/icon/moab015

Eleftheriadis P (2020) The German Constitutional Court's Weiss judgment is a Failure of German

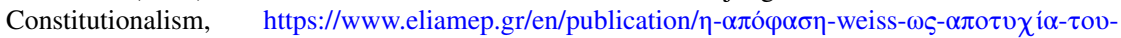
$\gamma \varepsilon \rho \mu \alpha \nu \imath \kappa o v ́ /$ and also: Germany's Failing Court, https://verfassungsblog.de/germanys-failing-court/

Eleftheriadis P (2020a) A Union of Peoples, OUP

Fallon F (2018) Law and Legitimacy in the Supreme Court, Cambr. (MA.)

Flynn T (2019) The Triangular Constitution. Constitutional Pluralism in Ireland, the EU, and the ECHR. Hart, Oxford

Gerstenberg O (2018) Euroconstitutionalism and its discontents. Oxford University Press

Gerstenberg O (2020) Fundamental rights and democratic sovereignty in the EU: the role of the Charter of Fundamental Rights of the EU (CFREU) in regulating the European Social Market Economy. Yearbook of European Law 39:199-227. https://doi.org/10.1093/yel/yeaa008

Grimm D (2020) (2020) A long time coming. German Law Journal 21:944-949. https://doi.org/10.1017/ glj. 2020.55

Haltern U (2021) Revolutions, real contradictions, and the method of resolving them: the relationship between the Court of Justice of the European Union and the German Federal Constitutional Court. I CON 19(1):208-240. https://doi.org/10.1093/icon/moab016

Meier-Beck P (2020) Ultra Vires? https://www.d-kart.de/en/blog/2020/05/11/ultra-vires/

Marsh D (2020) ECB steps up 'proportionality' commitment, Official Monetary and Financial Institutions Forum, 30. June 2020. https://www.omfif.org/2020/06/ecb-steps-up-proportionality-commi tment/\#: :text=The $\% 20$ ECB $\% 20$ specifically $\% 20$ mentioned $\% 20$ 'proportionality,council $\% 20$ mon etary $\% 20$ meetings $\% 20$ since $\% 202015$.\& text $=$ The $\% 20$ unprecedented $\% 20$ mass $\% 20 \mathrm{mailing} \%$ 20of,Bundestag\%20debate\%20on\%202\%20July

Mayer FC (2020) The ultra vires ruling: deconstructing the German Federal Constitutional Court's PSPP decision of 5 May 2020. Case Note European Constitutional Law Review 16:733-769. https://doi. org/10.1017/S1574019620000371

Mayer O (1924) Deutsches Verwaltungsrecht, 3. Aufl. München (Vorwort zur dritten Auflage)

Michelman F (2019) Political-liberal legitimacy and the question of judicial restraint. Jus Cogens 1:5975. https://doi.org/10.1007/s42439-019-00006-w

Mersch Y (2017) Central bank independence revisited. Keynote Address at the "Symposium on Building the Financial System of the 21st Century: An Agenda for Europe and the United States", at: https:// www.ecb.europa.eu/press/key/date/2017/html/sp170330.en.html

Mersch Y (2019) Necessity, proportionality and probity - central bank independence in unconventional times, https://www.ecb.europa.eu/press/key/date/2019/html/ecb.sp190327_4 4ccf5d35bc.en.html

Mersch Y (2020), In the spirit of European cooperation: introductory remarks, at https://www.ecb.europa. eu/press/key/date/2020/html/ecb.sp200702 87ce377373.en.html

Pistor K (2020) Germany's Constitutional Court Goes

Rogue, https://www.project-syndicate.org/commentary/german-constitutional-court-ecb-ruling-maythreaten-euro-by-katharina-pistor-2020-05

Rawls J (1999) The idea of public reason revisited, in: Collected Papers (S. Freeman, ed.), Cambr., MA. 
Sabel CF (2012) Dewey, democracy, and democratic experimentalism. In: Contemporary Pragmatism 9(2)

Sabel CF, Kessler J (2021) The uncertain future of administrative law, in Mark Tushnet, Ed., The Modern Administrative State: Reconstruction or Deconstruction?. Daedalus, Fall 2021:188-207. https://doi. org/10.1162/DAED_a_01867

Sabel CF, Victor DG (2022) Fixing the climate: strategies for an uncertain world (Princeton UP, forthcoming, on file with authors)

Sarmiento D, Weiler JHH (2020) The EU Judiciary after Weiss — proposing a new mixed chamber of the Court of Justice" at https://eulawlive.com/op-ed-the-eu-judiciary-after-weiss-proposing-a-newmixed-chamber-of-the-court-of-justice-by-daniel-sarmiento-and-j-h-h-weiler/

Shapiro M (1992) "The Giving Reasons Requirement," University of Chicago Legal Forum: Vol. 1992 , Article 8. Available at: https://chicagounbound.uchicago.edu/uclf/vol1992/iss1/8

Shklar, J (1964 / 1986) Legalism. Law, Morals, and Political Trials (Harvard UP)

Sunstein, C and Vermeule, A (2020) Law and Leviathan. Redeeming the Administrative State, Harvard UP

Tridimas T (2020) From barking to biting: reflections on the Bundesverfassungsgericht judgment of 5 May 2020, (ms. on file with author)

Tucker P (2018) Unelected power. The quest for legitimacy in central banking and the Regulatory State (Princeton UP)

Weiler JHH (2021) Why Weiss? I•CON, Vol. 19 No. 1, 179-187. https://doi.org/10.1093/icon/moab026

Publisher's Note Springer Nature remains neutral with regard to jurisdictional claims in published maps and institutional affiliations. 